\title{
Fertility map and horizontal soil potassium status of north-eastern region of Haryana
}

\author{
Koustav Mondal ${ }^{{ }^{*}}$ and Ramkala ${ }^{2}$ \\ ${ }^{1}$ Department of Agricultural Chemistry and Soil Science, Bidhan Chandra Krishi Viswavidyalaya, Mohanpur- \\ 741252 (West Bengal), INDIA \\ ${ }^{2}$ Department of Soil Science, CCS Haryana Agricultural University, Hisar -125004 (Haryana), INDIA \\ *Corresponding author. E-mail: koustavmonda12007@gmail.com
}

Received: April 1, 2016 Revised received: August 4, 2016; Accepted: November 10, 2016

\begin{abstract}
Considering soil fertility evaluation of any area for sustainable production, an experiment was conducted to investigate the horizontal soil potassium status $(K)$ of the soil surface of north-eastern region of Haryana. The study indicated that available $\mathrm{K}$ of surface soil samples ranged from 44 to $867 \mathrm{~kg} / \mathrm{ha}$ with a mean value of $148 \mathrm{~kg} / \mathrm{ha}$ in Ambala district. In panchkula district it ranged from 44 to $865 \mathrm{~kg} / \mathrm{ha}$ with a mean value of $138 \mathrm{~kg} / \mathrm{ha}$ where as in Yamunanagar district K content varied from 62 to $441 \mathrm{~kg} / \mathrm{ha}$ with a mean value of $147 \mathrm{~kg} / \mathrm{ha}$. Maximum K deficient samples were observed at Panchkula district that is $60.5 \%$ followed by Yamunanagar and Ambala, 36.3 and $30.2 \%$ respectively with an overall $41.3 \% \mathrm{~K}$ deficient samples. In case of Ambala $62.8 \%$ soil samples were mediumin $\mathrm{K}$ fertility and in case of Yamunanagar $52 \%$ soil samples were medium in $\mathrm{K}$ fertility. Nutrient index value for $\mathrm{K}$ was found 1.77, 1.76 and 1.47 in Ambala, Yamunanagar and Panchkula districts, respectively. On the basis of available surface soil $\mathrm{K}$ status a horizontal fertility map was prepared using GPS data. K fertilization is strongly suggested with recommended dose to check further depletion of soil available $\mathrm{K}$ of the surface layer.
\end{abstract}

Keywords: Fertility map, K status, Nutrient index value, Soil

\section{INTRODUCTION}

Maintaining appropriate level of soil fertility, especially plant nutrient availability, has a tremendous importance if agricultural land has to remain capable of sustaining crop production at an acceptable level. Soil fertility map is a geographical representation showing diversity of soil fertility status of a region and preparation of soil fertility map is a fast and efficient way of generating information about soil fertility of any region in a large scale basis which is very helpful to farmers.

Potassium $(\mathrm{K})$ is the seventh most abundant mineral in the earth crust averaging about $2.59 \%$. $\mathrm{K}$ is one of the major elements. $\mathrm{K}$ is the key element in soil chemistry and soil fertility because large portion of $\mathrm{K}$ is present in soil as a part of crystalline structure of primary and secondary minerals. Thus its status depends on parent material and subsequent stages of weathering of material (Solankey et al., 1991).

Importance of $\mathrm{K}$ in Indian agriculture has increased with intensification of agriculture. The gap between removal of $\mathrm{K}$ and its application to crop is widening. It is therefore imperative to understand dynamics of $\mathrm{K}$ in soil and application of $\mathrm{K}$-fertilizer according to needs of crops to provide balanced nutrition, harvest good yields and maintain the $\mathrm{K}$ status of soil. It has been estimated that in India, the $\mathrm{K}$ status in $13 \%$ soils was low, $37 \%$ medium and $50 \%$ in high category
(Motsara, 2002). After analyzing data from soil testing laboratories and published literature Pathak (2010) reported that $\mathrm{K}$ fertility of Indian soil either remained same or decreased.

Hassan (2002) found that among 371 districts of India for which information is available, the respective number of districts characterized as low, medium, and high are76, 190, and 105, respectively. Dahiya and Shanwal (2004) investigated soils of Haryana and reported K content of degraded mica in soils of Haryana has gone down from 10 to 5 percent as a result of intensive cultivation and low K fertilization. Bhandari et al. (1996) reported that more than 30 percent soils have changed from high $\mathrm{K}$ to medium category in a span of 20 years (1975-1995). Saini and Grewal (2014) reported the range of soil available $\mathrm{K}$ from 144 to $290 \mathrm{~kg} / \mathrm{ha}$ of some soils of Haryana.

Continuous application of lower fertilizer than the requirement results faster depletion of nutrient in soil. Over fertilization, on the other hand, is not only an economic loss, but also has a harmful effect on environment and crop growth. Fertility status of nutrient is thus very important to recommend optimum fertilization rate.

Therefore, keeping in view of above mentioned facts the present study was undertaken with the objective to investigate the status of $\mathrm{K}$ in soils of north -eastern region of Haryana (Ambala, Yamunanagar 
and Panchkula districts) and preparation of $\mathrm{K}$ status map.

\section{MATERIALS AND METHODS}

Collection and preparation of soil samples: For the investigation of status of $\mathrm{K}$ in north-eastern region of Haryana, surface soil samples $(0-15 \mathrm{~cm}$ depth) were collected at an average distance gap of $2-3 \mathrm{~km}$. from Ambala, Yamunanagar and Panchkula districts using GPS. These samples were air dried ground and passed through a $2 \mathrm{~mm}$ sieve and analyzed for different basic soil chemical properties and available $\mathrm{K}$.

$\mathrm{pH}$ of soil was determined in 1: 2, soil: water suspension at room temperature with single electrode Elico digital pH meter (Richards, 1954). Conductivity Bridge was used to measure the electrical conductivity of 1: 2, soil: water suspension after overnight equilibration (Richards, 1954). Organic carbon was determined according to the Wet Digestion Method as described by Walkley and Black (1934). Cation exchange capacity of each soil profile sample was determined by sodium acetate method (Jackson, 1973). Calcium carbonate of the soil was determined by Puri's (1930) method. 10.0 gram of soil in $200 \mathrm{ml}$ distilled water was titrated with $0.5 \mathrm{~N} \mathrm{H}_{2} \mathrm{SO}_{4}$ in the presence of bromothymol blue and bromocresol green indicators. The available $\mathrm{K}$ was extracted by neutral normal ammonium ammonium acetate and was determined by using Flame Photometer, as described by Richards (1954). Surface soil available K below 125 , in between 125 250 and above $250 \mathrm{~kg} / \mathrm{ha}$ has been considered as low, medium and high nutrient content, respectively.

Nutrient index values (NIV) of those districts were determined by using the following formula as de- scribed by Parker et al., 1951.

$\mathrm{NIV}=(\mathrm{SL}+2 \mathrm{SM}+3 \mathrm{SH})$

$$
/(\mathbf{S L}+\mathbf{S M}+\mathbf{S H})
$$

Where SL $=$ Number of samples of low in nutrient content

$\mathrm{SM}=$ Number of samples of medium in nutrient content $\mathrm{SH}=$ Number of samples of high in nutrient content

Nutrient index value below 1.5 , in between 1.5 to 2.5 and above 2.5 has been considered as low, medium and high, respectively.

Preparation of soil fertility map: Base map of the Ambala, Panchkula and Yamunanagar districts was digitized and geo-referenced. Polygons were superimposed on the geo-referred map. Latitude, longitude and analysis data were entered into attributed table and linked to GIS software for making thematic soil fertility maps as described by Mishra et al. (2014).

\section{RESULTS AND DISCUSSION}

Basic soil chemical properties of surface soil: Basic soil chemical properties of the surface soil samples of Ambala, Panchkula and Yamunanagar districts were determined and their ranges with mean values are presented in Table 1. Soil reactions of these three districts were found neutral to mostly alkaline. The $\mathrm{pH}$ of the soil samples varied from 6.6 to $10.1,6.3$ to $8.6,6.2$ to 8.8 in Ambala, Panchkula and Yamunanagar districts respectively with a overall range from 6.2 to 10.1 . Their salinity ranged from 0.1 to $1.9 \mathrm{dSm}^{-1}$ with a mean value of $0.4 \mathrm{dSm}^{-1}$ in Ambala, 0.1 to $1.0 \mathrm{dSm}^{-1}$ with a mean value of $0.2 \mathrm{dSm}^{-1}$ in Panchkula and 0.1 to $1.9 \mathrm{dSm}^{-1}$ with a mean value of $0.4 \mathrm{dSm}^{-1}$ in Yamunanagar district with a overall range from 0.1 to 1.9 . These electrical conductivity values of the three dis-

Table 1. Basic soil chemical properties of few districts of north-eastern region of Haryana.

\begin{tabular}{lllll}
\hline \multirow{2}{*}{ Soil property } & Districts & & & \\
\cline { 2 - 5 } & Ambala & Panchkula & Yamunanagar & Overall \\
\hline $\mathrm{pH}$ & $6.6-10.1$ & $6.3-8.6$ & $6.2-8.8$ & $6.2-10.1$ \\
$\mathrm{EC}\left[\mathrm{dSm}^{-1}\right]$ & $0.1-1.9(0.4)$ & $0.1-1.0(0.2)$ & $0.1-1.9(0.4)$ & $0.1-1.9(0.3)$ \\
$\mathrm{OC}[\%]$ & $0.19-0.6(0.33)$ & $0.22-.72(0.38)$ & $0.20-0.66(0.34)$ & $0.19-0.72(0.36)$ \\
$\mathrm{CaCO} 3[\%]$ & Trace-1.65 & Trace-2.87 & Trace- 4.4 & 3.4 \\
$\mathrm{CEC}\left[\mathrm{cmol}(\mathrm{p}+) \mathrm{kg}^{-1}\right]$ & $3.0-24.4$ & $3.2-16.4$ & $3.8-19.4$ & 3.4 \\
\hline
\end{tabular}

Values in the parenthesis indicate mean values.

Table 2. Status, nutrient index values and percent deficiencies of available K in Ambala, Panchkula and Yamunanagar districts of Haryana.

\begin{tabular}{|c|c|c|c|c|}
\hline \multirow[b]{2}{*}{ Soil available $\mathbf{K}$} & \multicolumn{4}{|l|}{ Districts } \\
\hline & $\begin{array}{l}\text { Ambala } \\
{[86]}\end{array}$ & $\begin{array}{l}\text { Panchkula } \\
{[76]}\end{array}$ & $\begin{array}{l}\text { Yamunanagar } \\
{[102]}\end{array}$ & $\begin{array}{l}\text { Overall } \\
{[264]}\end{array}$ \\
\hline Available $\mathrm{K}$ range [kg/ha] & $44-867$ & $44-865$ & $62-441$ & $44-867$ \\
\hline Average available $\mathrm{K}[\mathrm{kg} / \mathrm{ha}]$ & 148 & 138 & 147 & 145 \\
\hline No of samples high in $\mathrm{K}$ & $6(7.0 \%)$ & $6(7.9 \%)$ & $12(11.8 \%)$ & $24(9.1 \%)$ \\
\hline No of samples medium in $\mathrm{K}$ & $54(62.8 \%)$ & $24(31.6 \%)$ & $53(52.0 \%)$ & $131(49.6 \%)$ \\
\hline No of samples low in $\mathrm{K}$ & $26(30.2 \%)$ & $46(60.5 \%)$ & $37(36.3 \%)$ & $109(41.3 \%)$ \\
\hline Nutrient index value & 1.77 & 1.47 & 1.76 & 1.67 \\
\hline Percent deficient samples & $30.2 \%$ & $60.5 \%$ & $36.3 \%$ & $41.3 \%$ \\
\hline
\end{tabular}

Total no. of samples are indicated in [ ]. 


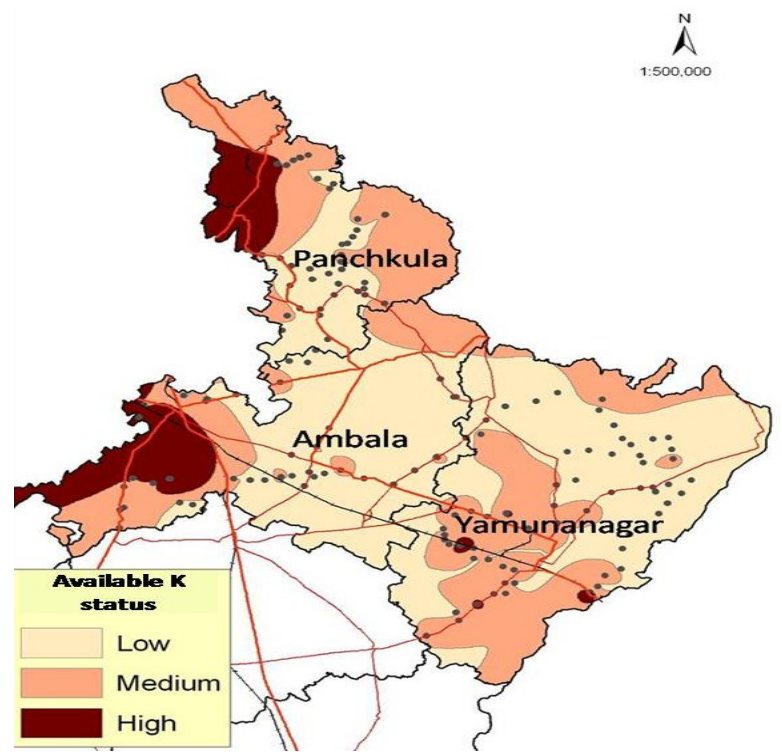

Fig. 1. Horizontal soil available $K$ status map of northeastern region of Haryana (Panchkula, Ambala and Yamunanagar districts).

tricts represents that salt content of the soil was quite low and soil is normal for crop growth. Soil organic carbon contents of all the three districts were found low to medium. It varied from 0.19 to $0.63 \%$ in Ambala, 0.22 to $0.72 \%$ in Panchkula and 0.2 to $0.66 \%$ in Yamunanagar district with mean values of $0.33,0.38$ and $0.34 \%$ respectively. Overall range of organic carbon varied from 0.19 to 0.72 with a mean value of 0.36. Cation exchange capacity (CEC) of these soils varied from 3.0 to $24.4 \mathrm{cmol}(\mathrm{p}+) \mathrm{kg}^{-1}$ in Ambala, 3.2 to $16.4 \mathrm{cmol}(\mathrm{p}+) \mathrm{kg}^{-1}$ in Panchkula and 3.8 to 19.4 cmol $(\mathrm{p}+) \mathrm{kg}^{-1}$ in Yamunanagar district with a overall range from 3.0 to $24.4 \mathrm{cmol}(\mathrm{p}+) \mathrm{kg}^{-1}$. The calcium carbonate content in the soils of these three districts were low and it ranged from traces to $1.7 \%$ in Ambala, traces to $2.9 \%$ in Panchkula and traces to $4.4 \%$ in Yamunanagar district with a overall range from trace to 4.4. Saini and Grewal (2014) found the ranges of Electrical Conductivity from 0.12 to $1.25 \mathrm{dSm}^{-1}$, Cation Exchange Capacity from 3.10 to $31.05 \mathrm{cmol}(\mathrm{p}+) \mathrm{kg}^{-1}$ and Organic Carbon from 0.16 to $0.48 \%$ while on different forms of $\mathrm{K}$ and their relationship with different physico chemical properties of soils of few districts of Haryana under different crop rotation. These results are very similar to ours.

Status of K: Average K contents in the soils of the three districts were found medium (Table2). Available $\mathrm{K}$ ranged from 44 (Kashrolivillege) to 867 (Kalumazra village) $\mathrm{kg} / \mathrm{ha}$ with a mean value of $148 \mathrm{~kg} / \mathrm{ha}$ in Ambala district. In Panchkula district it ranged from 44 (Mattawala village) to 865 (Ramgarh village) $\mathrm{kg} / \mathrm{ha}$ with a mean value of $138 \mathrm{~kg} / \mathrm{ha}$ where as in Yamunanagar district $\mathrm{K}$ content varied from 62 (Bhallomazra village) to 441 (Bamboli village) $\mathrm{kg} / \mathrm{ha}$ with a mean value of $147 \mathrm{~kg} / \mathrm{ha}$. Mushtaq and Rajkumar (2008) found similar soil available K content while working on high altitude zones of some paddy soils of lesser Himalayas. These results are also in agreement with Saini and Grewal (2014). The maximum values of available $\mathrm{K}$ content in Ambala and Panchkula districts may be due to higher fertilization. Pathak (2010) reported medium K fertility status of Haryana at the end of the last century. Kumar et al. (2014) reported soil available $\mathrm{K}$ ranged from 208 to $821 \mathrm{~kg} / \mathrm{ha}$ in vertisols of Kabeerdham district of Chhattisgarh which is very similar to Ambala and Yamunanagar districts. These results support our findings. These results are also in conformity with the findings of Dhaliwal et al, (2004) for rice-wheat cropping system in Punjab and Dinagaran et al. (2006) found that exchangeable $\mathrm{K}$ content in soils varied from 145 to $400 \mathrm{mg} / \mathrm{kg}$ with a mean value of $220 \mathrm{mg} / \mathrm{kg}$ in some representative soil series of Haryana. Their findings are similar to ours. Nutrient index values and percent of samples under high, medium and low are presented in Table2. In the present investigation it was found that maximum percent deficiency of $\mathrm{K}$ was observed at Panchkula district that is $60.5 \%$ followed by Yamunanagar and Ambala 36.3 and $30.2 \%$ respectively with an overall percent deficiency of $41.3 \%$ of those three districts. In case of Ambala and Yamunanagar districts maximum percent soil samples was in medium that is 62.8 and $52 \%$ respectively. Nutrient index value for $\mathrm{K}$ was found 1.77, 1.76 and 1.47 in Ambala, Yamunanagar and Panchkula districts, respectively with an overall nutrient index value of 1.67. Pathak (2010) while determining the trend of fertility status of Indian soil found medium $\mathrm{K}$ fertility in most of the states of India. In Haryana potassium fertility increased from 2.00 in 1967 to 2.80 in 1977 and then decreased to 2.05 in 1997.

Fertility status map: Status of K of north-eastern regions of Haryana was found low to medium with a medium nutrient index value for Ambala and Yamunanagar district and low nutrient index value for Panchkula district. And based on those data a status map of soil available $\mathrm{K}$ of Amabala, panchkula and Yamunanagar districts was prepared which is depicted as Fig. 1.

\section{Conclusion}

Soils of north-eastern region of Haryana were slightly alkaline in reaction, non-saline in nature having low to medium in organic carbon content and low in calcium carbonate content. Maximum percent deficiency of $\mathrm{K}$ in the north-eastern region of Haryana was found in Panchkula followed by Yamunanagar and Ambala. Due to intensive irrigated agriculture in the study area, recommended fertilization is strongly recommended. However, the information generated in the present 
study can be used for temporal study of soil $\mathrm{K}$ fertility or can be used for comparison of fertility status in future.

\section{ACKNOWLEDGEMENTS}

Authors are grateful to Haryana Space Application Centre (HARSAC), Department of Science \& Technology, Haryana, CCS HAU Campus, Hisar-125004, for making the fertility map and corresponding author thank ICAR, New Delhi for providing financial support as Junior Research Fellowship during the research.

\section{REFERENCES}

Bhandari, D.K., Sharma, J.C., Mehta, R.S., Suneja, B.K., Dev, S. and Sangwan, O.P. (1996). Available potassium in Haryana soils, In: Dev, G. and Oswal, M.C. (eds.) Use of potassium in Haryana Agriculture. Potash Research Institute of Canada, India Progrramme, Gurgaon, India. pp: 18-26

Dahiya, S.S. and Shanwal, A.V. (2004). Potassium mining and agriculture sustainability-Haryana Scenario. Fertilizer News, 49: 57-71

Dhaliwal, A.K., Gupta, R.K., Singh, Y., Sharma, B.D. and Singh, B. (2004). Distribution of different forms of potassium in benchmark soil series under rice-wheat cropping system in Punjab. J. Pot. Res., 20: 12-21

Dinagaran, A., Singh, N., Grewal, K.S., Dahiya, S.S. and Duhan, B.S. (2006). Distribution of potassium in some representative soil series of Haryana in relation to soil properties. Haryana agric. Univ. J. Res., 36: 113-118

Hassan, R. (2002). Potassium status of soils in India. Better. Crops Int., 16(2): 3-5

Jackson, M.L. (1973). Soil Chemical Analysis. Prentice Hall of India Pvt. Ltd., New Delhi.

Kumar, A., Mishra, V.N., Srivastav, L.K. and Banwasi, R.
(2014). Evaluations of soil fertility status of available major nutrients (N,P \& K) and micronutrients (Fe, Mn, $\mathrm{Cu} \& \mathrm{Zn}$ ) in Vertisol of Kabeerdham district of Chhattisgarh, India. Int. J. Interdiscipl. Multidiscipl. Stud., 1 (10): $72-79$

Mishra, A., Pattnaik, T., Das, D. and Das, M. (2014). Soil fertility maps preparation using GPS and GIS in Dhenkanal District, Odisha, India. Int. J. Plant \& Soil Sci., 3 (8): 986-994

Motsara, M.R. (2002). Available nitrogen, phosphorus and potassium status of Indian soils as depicted by soil fertility maps. Fertilizer News, 47 (8):15-21

Mushtaq, A.W. and Rajkumar. (2008). Distribution of potassium and clay minerals assemblage in some paddy soils of Lesser Himalayas. Agropedology, 18 (2): 98-105

Parker, F.W., Nelson, W.L., Winters, E. and Miles, I.E. (1951). The broad interpretation and application of soil test Information. Agron. J., 43:105-112

Pathak, H. (2010). Trend of fertility status of Indian soils. Curr. Adv. Agric. Sci., 2 (1): 10-12

Puri, A.N. (1930). Soil-Their physics and Chemistry. Reinnlad Publ. Cropn. NewYork.

Richards, I.A. (Ed.) (1954). Diagnosis and improvement of saline alkali soils. USDA Handbook No. 60. Oxford and IBH Publishing Co., London.

Saini, J., Grewal, K.S. (2014). Vertical distribution of different forms of potassium and their relationship with different soil properties in some Haryana soil under different crop rotation. Adv Plants Agric Res., 1 (2): 00010

Solankey, B.S., Shinde, D.A. and Mahajan, A.K. (1991). Potassium status of Antralia and Panchdaria swell-shrink soil series of Madhya Pradesh. J. Pot. Res., 7 (1): 9-19

Walkley, A. and Black, I.A. (1934). An examination of dagtjareff methods for determining soil organic matter and a proposed modification of the chromic acid titration 